\title{
Effect of humidity on the composition of isoprene photooxidation secondary organic aerosol
}

\author{
T. B. Nguyen ${ }^{1}$, P. J. Roach ${ }^{2, *}$, J. Laskin ${ }^{2}$, A. Laskin ${ }^{3}$, and S. A. Nizkorodov ${ }^{1}$ \\ ${ }^{1}$ Department of Chemistry, University of California, Irvine, California, 92697, USA \\ ${ }^{2}$ Chemical and Materials Sciences Division, Pacific Northwest National Laboratory, Richland, Washington, 99352, USA \\ ${ }^{3}$ Environmental Molecular Sciences Laboratory, Pacific Northwest National Laboratory, Richland, Washington, 99352, USA \\ *now at: Roach \& Associates LLC, Seymour, WI, 54165, USA
}

Received: 5 March 2011 - Published in Atmos. Chem. Phys. Discuss.: 18 March 2011

Revised: 6 July 2011 - Accepted: 7 July 2011 - Published: 18 July 2011

\begin{abstract}
The effect of relative humidity (RH) on the composition and concentrations of gas-phase products and secondary organic aerosol (SOA) generated from the photooxidation of isoprene under high- $\mathrm{NO}_{\mathrm{x}}$ conditions was investigated. Experiments were performed with hydrogen peroxide as the $\mathrm{OH}$ precursor and in the absence of seed aerosol. The relative yields of most gas-phase products were the same regardless of initial water vapor concentration with exception of hydroxyacetone and glycolaldehyde, which were considerably affected by RH. A significant change was observed in the SOA composition, with many unique condensed-phase products formed under humid $(90 \% \mathrm{RH})$ vs. dry $(<2 \% \mathrm{RH})$ conditions, without any detectable effect on the rate and extent of the SOA mass growth. There is a $40 \%$ reduction in the number and relative abundance of distinct particlephase nitrogen-containing organic compounds (NOC) detected by high resolution mass spectrometry. The suppression of condensation reactions, which produce water as a product, is the most important chemical effect of the increased RH. For example, the total signal from oligomeric esters of 2-methylglyceric acid was reduced by about $60 \%$ under humid conditions and the maximum oligomer chain lengths were reduced by 7-11 carbons. Oligomers formed by addition mechanisms, without direct involvement of water, also decreased at elevated RH but to a much smaller extent. The observed reduction in the extent of condensationtype oligomerization at high RH may have substantial impact on the phase characteristics and hygroscopicity of the
\end{abstract}

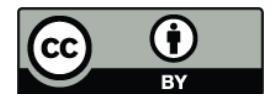

Correspondence to: S. A. Nizkorodov (nizkorod@uci.edu) isoprene aerosol. The reduction in the amount of organic nitrates in the particle phase has implications for understanding the budget of NOC compounds.

\section{Introduction}

Isoprene (2-methyl-1,3-butadiene, $\mathrm{C}_{5} \mathrm{H}_{8}$ ) is a major source of secondary organic aerosol (SOA), generated as a result of its atmospheric photooxidation by the hydroxyl $(\mathrm{OH})$ radical (Henze and Seinfeld, 2006; Heald et al., 2008; van Donkelaar et al., 2007). In the urban atmosphere, the photooxidation of isoprene proceeds in the presence of nitrogen oxides $(\mathrm{NO}+$ $\mathrm{NO}_{2}=\mathrm{NO}_{\mathrm{x}}$ ), henceforth referred to as high- $\mathrm{NO}_{\mathrm{x}}$ conditions, and results in formation of nitrogen-containing organic compounds (NOC) (see (Finlayson-Pitts and Pitts, 2000), and references therein). Isoprene SOA has substantial influence on climate by contributing to the pool of cloud condensation nuclei (CCN) (see Carlton et al., 2009, and references therein). Furthermore, the photooxidation of isoprene produces important biogenic SOA tracers 2-methyltetrols and 2-methylglyceric acid (2MGA) (Claeys et al., 2004; Wang et al., 2005; Alves et al., 2010).

Water is ubiquitous in the atmosphere, and relative humidity (RH) may affect the mechanism of SOA formation, chemical composition and physical properties of SOA (Seinfeld et al., 2001; de P. Vasconcelos et al., 1994; Poulain et al., 2010). $\mathrm{RH}$ controls the liquid water content (LWC) of the aerosol (Volkamer et al., 2009), and therefore any chemical reaction or physical process that involves water as a reactant, product, or solvent is affected. With a typical hygroscopic growth factor of 1.1 at $85 \%$ RH for biogenic SOA (Varutbangkul et al.,

Published by Copernicus Publications on behalf of the European Geosciences Union. 
a)

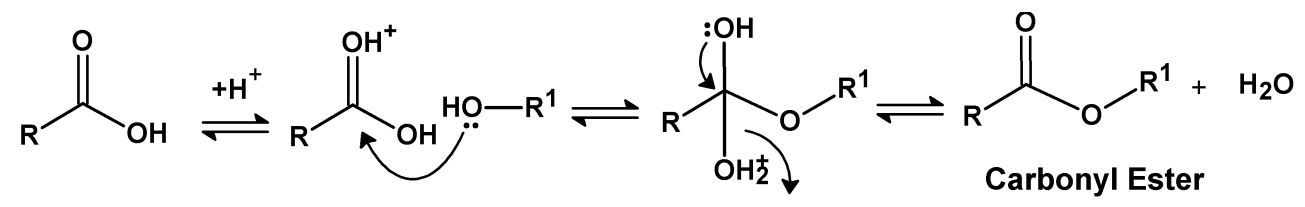

b)

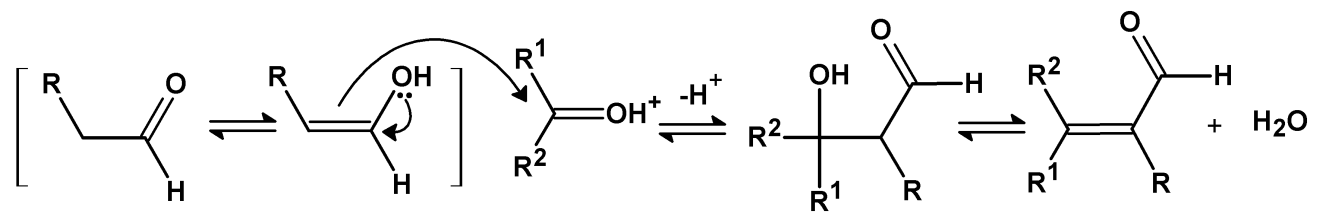

Keto

Enol

c)

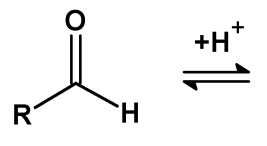

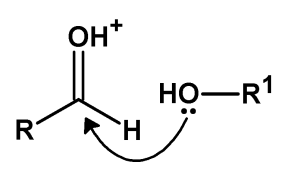

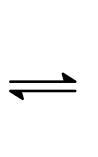

Aldol

Fig. 1. Mechanisms of acid-catalyzed oligomeric growth by (a) esterification, (b) aldol condensation and (c) hemiacetal formation. Aldol condensation involves two steps: an addition step to yield the aldol and a condensation step to yield a $\beta$-unsaturated aldehyde. The nucleophiles in reactions (a-c) may be the enol tautomers of carbonyls. Each reaction is affected by liquid water content either through direct involvement of water in the reaction or indirectly through solvation.

2006), the particle LWC should be of the order of $30 \%$ by volume. This may be sufficient to have a substantial fraction of organic compounds partition in the aqueous phase and get involved in aqueous chemistry and photochemistry.

Isoprene photooxidation SOA has been studied under a variety of RH conditions (Carlton et al., 2009). Dommen et al. (2006) studied SOA yields from isoprene photooxidation generated without inorganic seeds in the RH range of 2-84 \% and found that high RH does not considerably change the SOA yields and gas-particle partitioning in the SOA formation process. However, a recent study by Zhang et al. (2011) found an approximately 2 -fold increase in SOA yield in the dry vs. humid conditions when using ammonium sulfate seed aerosol. The conclusions from these two studies are not consistent with the modeling predictions that isoprene SOA yield is enhanced under humid conditions (Couvidat et al., 2011). The disagreement between the isoprene SOA yields measured under different RH conditions in Dommen et al. (2006) vs. Zhang et al. (2011) experiments is likely due to the absence and presence of seed particles, but other factors may also contribute. The present work does not use seed particles and therefore is more directly comparable to the work of Dommen et al. (2006) with respect to the RH effect on the SOA yields.

The role of RH in determining the SOA composition and yield is difficult to predict a priori as there are several types of processes that may be induced by LWC. One possible consequence of LWC is an increase in reactive uptake kinetics of volatile organic compounds (VOC) into the aerosol phase because gas-phase carbonyls, like glyoxal and methylglyoxal, may hydrate on particles containing adsorbed water, and subsequently polymerize into less volatile products (Liggio et al., 2005b, a; Jang and Kamens, 2001; Jang et al., 2003; Axson et al., 2010; Loeffler et al., 2006; Altieri et al., 2008; Tan et al., 2010; Fu et al., 2009; Jayne et al., 1992; Corrigan et al., 2008). In this case, water serves as a reactant during the hydration stage and accelerates oligomerization of the hydrated carbonyls, leading to an increase in the aerosol yield and increased abundance of aerosol-phase hemiacetal products. Even without the hydration step, the presence of surface water may significantly alter the efficiency of reactive uptake of VOC (Ewing, 2004).

Figure 1 shows the most common chemical equilibria involving SOA constituents which may be affected by the increased LWC. Condensation reactions like esterification (Fig. 1a) and the aldol condensation (Fig. 1b), which produce a water molecule as reaction product, have been shown to be important in biogenic SOA formation, especially under high- $\mathrm{NO}_{\mathrm{x}}$ conditions (Surratt et al., 2006; Szmigielski et al., 2007; Altieri et al., 2008; Barsanti and Pankow, 2005; Casale et al., 2007; Tolocka et al., 2004). Addition reactions including hemiacetal formation (Fig. 1c) and aldol formation (intermediate in Fig. 1b), where the molecular formula of the product is a simple result of adding the reactant formulas, are also important in the formation of SOA from biogenic precursors, especially under the low- $\mathrm{NO}_{\mathrm{x}}$ conditions (Surratt et al., 2006; Iinuma et al., 2009; Barsanti and Pankow, 2004). The addition products may stem from heterogeneous uptake; for example: hemiacetals derived from isoprene have been demonstrated to form in the acid-catalyzed reactive uptake of gas-phase epoxydiols (Surratt et al., 2010). 
The increase of LWC will likely impede esterification and aldol condensation by shifting the chemical equilibrium towards the reactants but have little effect on the formation of hemiacetal, which does not involve water directly. However, an enhancement of aldol formation due to increased LWC is also possible in special cases due to shifts in the keto-enol tautomerism. For example, in malonic acid particles, the concentration of the reactive enol form increased by an order of magnitude for particles exposed to $90 \%$ vs. $2 \% \mathrm{RH}$ (Ghorai et al., 2011). The suppression of oligomerization results in more volatile aerosol constituents, which may reduce the SOA yield.

Due to the different effects of high RH - enhancement in the reactive uptake of VOC and suppression of condensation oligomerization reactions - the composition of SOA will likely be affected by $\mathrm{RH}$, with the change in the extent of oligomerization being positive or negative depending on which type of reaction is dominant. The aerosol mass may also change, especially if high RH helps take up volatile organics. The changes in composition affects the physical characteristics of the SOA, e.g. hygroscopicity, viscosity, etc., which may have profound implications in the atmosphere. In this work, we investigate the effect of RH on the molecular composition of SOA produced by isoprene photooxidation using high-resolution mass spectrometry and the effect of $\mathrm{RH}$ on the relative SOA mass yields using traditional techniques.

\section{Experimental}

SOA was generated under high- $\mathrm{NO}_{\mathrm{x}}$ conditions (isoprene: $\mathrm{NO}_{\mathrm{x}} \approx 1: 3$ ) in the absence of seed aerosol in a $5 \mathrm{~m}^{3}$ Teflon chamber surrounded by a bank of UV-B lights. Particle number concentration was monitored by a scanning mobility particle sizer (SMPS Model 3080, TSI Inc.), ozone was monitored by a Thermo Model 49 i photometer $( \pm 1 \%$ stated accuracy), $\mathrm{NO}$ and $\mathrm{NO}_{\mathrm{y}}$ were measured with Thermo Model $42 \mathrm{i}$ chemiluminescence analyzer ( $\pm 1 \%$ stated accuracy), temperature $\left( \pm 1{ }^{\circ} \mathrm{C}\right)$ and relative humidity ( $\pm 2 \% \mathrm{RH}$ units) were monitored by a Vaisala HMT330 probe, and volatile hydrocarbons (isoprene and first-generation products) were observed in real time by a proton-transfer-reaction time-offlight mass spectrometer (PTR-ToF-MS, Ionicon Analytik). The PTR-ToF-MS had a mass resolving power of around 1600 at $\mathrm{m} / z 69.07$ (protonated isoprene). Its response was calibrated with respect to isoprene and common isoprene photooxidation products. Prior to each experiment, the Teflon chamber was filled with zero air humidified to desired value of RH using a Nafion multi-channel humidifier (Perma Pure FC125). NO was introduced in the chamber by adding a calibrated volume of an NO primary standard (Praxair, $5000 \mathrm{ppm}$ in $\mathrm{N}_{2}$ ). The initial mixing ratio of $\mathrm{NO}$ was $600 \mathrm{ppb}$. There was also up to $100 \mathrm{ppb}$ of $\mathrm{NO}_{2}$ present initially, presumably formed during mixing of the $5000 \mathrm{ppm}$
NO standard with the air in the chamber. Hydrogen peroxide $\left(\mathrm{H}_{2} \mathrm{O}_{2}\right)$ was used as an $\mathrm{OH}$ precursor for gas-phase oxidation of isoprene and its primary oxidation products. A measured volume of aqueous $\mathrm{H}_{2} \mathrm{O}_{2}$ (Aldrich $30 \%$ by volume), corresponding to $2 \mathrm{ppm} \mathrm{H}_{2} \mathrm{O}_{2}$ in the chamber, was injected into a bulb and carried into the chamber with a flow of zero air. A measured volume of isoprene (Aldrich, 99\% purity) was similarly injected with a microliter syringe corresponding to an initial mixing ratio of $250 \mathrm{ppb}$. After all the precursors were injected, the mixture was exposed to the UV-B radiation, producing $\mathrm{OH}$ by photolysis of $\mathrm{H}_{2} \mathrm{O}_{2}$. The $\mathrm{OH}$ concentration of $\sim 4 \times 10^{7}$ molec $\mathrm{cm}^{-3}$ was estimated from the observed decay rate of isoprene.

Under high $\mathrm{RH}$ conditions, $\mathrm{H}_{2} \mathrm{O}_{2}$ may partition into the adsorbed water on particles and potentially contribute to aqueous photochemistry (Kroll et al., 2006). We estimate that the contribution of aqueous photochemistry to the production of $\mathrm{OH}$ is negligible under our experimental conditions, largely because we do not use inorganic seeds. The hygroscopic growth factors (GF) for model biogenic OA are in the range of 1.05-1.10 (Virkkula et al., 1999), which are much smaller than the corresponding GF of 1.5-2.1 reported (Virkkula et al., 1999; Cruz and Pandis, 2000) for inorganic salts typically used as seeds in aerosol chamber experiments. This helps suppress the particle LWC, and minimize the rate of the aqueous photochemistry. The rates of gas-phase oxidation of isoprene and its derivatives do not change between dry and humid conditions (Fig. 2a) confirming that the gasphase $\mathrm{OH}$ is not significantly depleted due to partitioning of $\mathrm{H}_{2} \mathrm{O}_{2}$ in the particle aqueous phase.

Experiments were performed in the temperature range of $22-26{ }^{\circ} \mathrm{C}$. The initial values of RH were $<2 \%$ for "dry" experiments and $\sim 90 \%$ for "humid" experiments. These values were chosen to maximize the differences in the SOA composition induced by the particle LWC without the risk of water condensation in the chamber. The actual RH experienced by the reacting mixture was lower at the end of the reaction period $(70-80 \% \mathrm{RH})$ due to a slight rise in temperature $\left(3-5^{\circ} \mathrm{C}\right)$ in the chamber during the photooxidation. For the remainder of the article, we will be referring to these conditions as "dry" and "humid". The sheath flow in the SMPS's differential mobility analyzer (DMA) column was maintained at low RH $(<10 \%$ when DMA was connected to the humidified chamber). We assumed that most water evaporated quickly upon contact of the aerosol flow (0.3 SLM) with the sheath flow (3 SLM), without significant loss of organic material from particles by co-evaporation with water. Assuming that it is indeed the case, the SMPS measurements should provide the dry aerosol mass concentration. A particle density of $1.2 \mathrm{~g} \mathrm{~cm}^{-3}$ typical of biogenic SOA was assumed for dry SOA material (Zelenyuk et al., 2008; Malloy et al., 2009; Shilling et al., 2009; Bahreini et al., 2005), regardless of the humidity in the chamber during the SOA formation. We note that it is not necessary to know the absolute density value as we will be comparing the relative SOA mass yields 


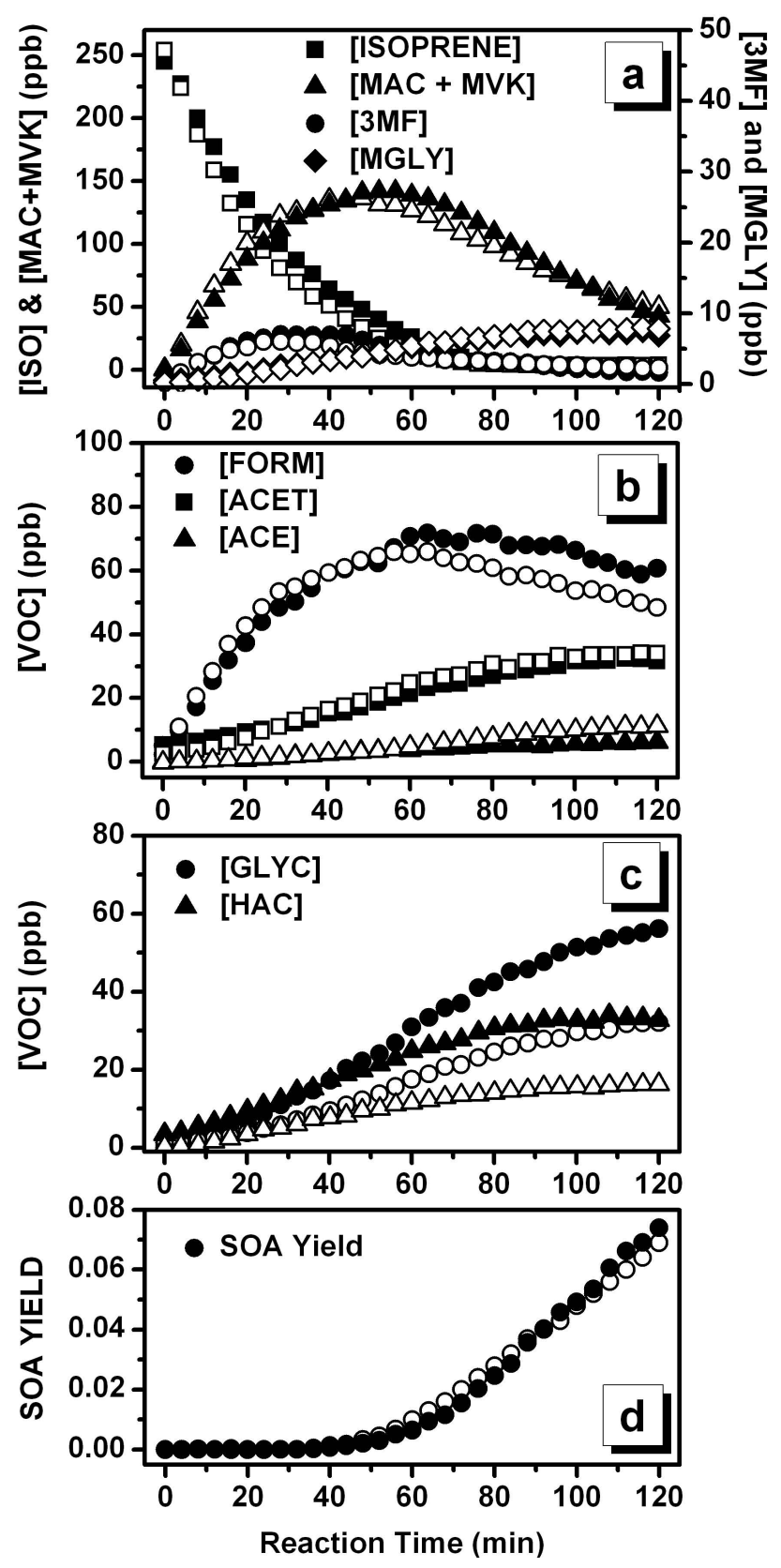

Fig. 2. Time dependent concentrations of selected species in the chamber during the photooxidation. Open markers refer to dry conditions and filled markers refer to humid conditions. PTR-ToF-MS mixing ratios of (a) isoprene, methylvinylketone $(\mathrm{MVK})+$ methacrolein $(\mathrm{MAC}), 3$-methylfuran (3MF), methylglyoxal (MGLY) (b) formaldehyde (FORM), acetaldehyde (ACET), acetone (ACE) (c) glycolaldehyde (GLYC) and hydroxyacetone (HAC). (d) The relative time-dependent SOA yield from isoprene photooxidation does not change with respect to initial concentration of water vapor in the chamber. The time-dependent SOA yield

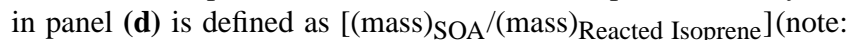
oxidation of MAC and MVK also contributes to SOA mass). between the dry and humid experiments. However, the readers should be aware of the limitations of measurements of the relative SOA mass yields by this method in view of the assumptions discussed above.

The photooxidation time was $2 \mathrm{~h}$, after which the SOA loading was $\sim 40 \mu \mathrm{g} \mathrm{m}^{-3}$. At that time, isoprene completely decayed and first generation products (methyl vinyl ketone, methacrolein, and 3-methylfuran) were also nearly completely removed. The concentration of ozone after the experiments increased to about $200 \mathrm{ppb}$. The experiments were performed in an identical manner, within a span of several days, with the only difference being the initial chamber RH. At least three samples were generated for each set of conditions. PTR-ToF-MS spectra showed excellent reproducibility in the time dependence of concentrations of isoprene and its major oxidation products. Blank experiments were performed identically to the sample experiments, but in the absence of UV radiation. The blank and background particle mass concentrations were $<0.01 \mathrm{\mu g} \mathrm{m}^{-3}$. Aerosols were collected using a $301 \mathrm{~min}^{-1}$ micro-orifice uniform deposition cascade impactor (MOUDI) on aluminum foils and PTFE substrates (Whatman, $2 \mu \mathrm{m}$ pore size). Samples from stages 6-10 (covering the particle size range of $0.056-0.56 \mu \mathrm{m}$ ) were used in the analysis. The substrates with collected samples were placed in plastic holders, vacuum-sealed in gas-impermeable bags, and frozen in anticipation of off-line analysis.

The SOA samples were analyzed using a high-resolution linear ion trap (LTQ-) Orbitrap ${ }^{\mathrm{TM}}$ (Thermo Corp.) mass spectrometer. The instrument was equipped with an electrospray ionization (ESI) and nanospray desorption electrospray ionization (nano-DESI) sources (Roach et al., 2010a, b). ESI is well-suited for analysis of SOA samples extracted in water and/or organic solvents, and is the common technique for the analysis of dissolved organic matter. NanoDESI, a sensitive ambient ionization technique that can detect nanograms of SOA material on surfaces without sample preparation prior to analysis, is better suited for the analysis of labile molecules (Roach et al., 2010a). Both techniques were used to obtain spectra in both positive and negative ionization modes. Analyte molecules are detected as $[\mathrm{M}+\mathrm{H}]^{+}$ and $[\mathrm{M}+\mathrm{Na}]^{+}$ions in the positive ion mode and as $[\mathrm{M}-\mathrm{H}]^{-}$ in the negative ion mode. A mixture (1:1 by volume) of acetonitrile and water (Acros Organics, HPLC grade) served as the solvent in ESI and the eluent in nano-DESI. The concentration of analyte in ESI was $c a .40 \mu \mathrm{g} \mathrm{ml}^{-1}$ (resulting from extraction of substrates into $1 \mathrm{ml}$ of the solvent). The solvent-analyte contact time in nano-DESI on the substrate surface was in the range of 1-3 min. Background mass spectra were taken on substrates obtained from blank experiments; they were not significantly different from pure solvent spectra. The mass resolving power of the instrument was $60000 \mathrm{~m} / \Delta \mathrm{m}$ at $m / z$ 400. Mass calibrations with a commercial standard mixture of caffeine, MRFA, and Ultramark 1621 (MSCAL5, Aldrich) were performed in intervals of 
several hours in both ionization modes to maintain high mass accuracy $(0.5 \mathrm{ppm}$ at $\mathrm{m} / \mathrm{z}, 500)$. Data were collected for a mass range of $m / z$ 50-2000. The spray voltage was $4 \mathrm{kV}$ and the solvent flow rate was $0.5 \mu \mathrm{min}^{-1}$.

\section{Results}

\subsection{SOA Yield and Gas-Phase Reaction Products}

PTR-ToF-MS was used to simultaneously track all VOC with proton affinities (PA) greater than the PA of water $\left(697 \mathrm{~kJ} \mathrm{~mol}^{-1}\right)$, including isoprene itself, with $18 \mathrm{~s}$ timeresolution. The humidity of the sampled air affects the extent of the PTR ionization. Under normal operation conditions, humidity alters the PTR ion concentrations by less than 5\% (Hewitt et al., 2003). However, the ion signal of VOC with PA similar to the PA of water, like formaldehyde $\left(718 \mathrm{~kJ} \mathrm{~mol}^{-1}\right)$, may be affected by more than $5 \%$ due to the backward protonation of $\mathrm{H}_{3} \mathrm{O}^{+}$primary ions at higher sample inlet humidity. This $\mathrm{RH}$ effect theoretically decreases ion signal under higher inlet flow RH. The ion signals for formaldehyde were corrected at the relevant drift potential $\left(U_{\text {drift }}=600 \mathrm{~V}\right)$ using the procedure reported by Inomata et al. (2008).

We generally do not observe significant differences in the PTR-ToF-MS time-dependent traces of the major VOC products monitored between the dry and humid conditions. Figure 2a shows the decay of isoprene and the formation of the first- and second-generation products methacrolein (MAC), methylvinyl ketone (MVK), 3-methylfuran (3MF), and methylglyoxal (MGLY). MAC and MVK are detected as an isobaric pair. The time-dependent traces of formaldehyde (FORM), acetaldehyde (ACET) and acetone (ACE) are shown in Fig. 2b. The time-dependent trace of FORM shows that at approximately the 60 min mark, after almost all isoprene has been reacted, the decay of FORM is reduced in the presence of water vapor. However, as gas-phase FORM has both photolysis loss channels (Moore and Weisshaar, 1983) and sources due to isoprene photooxidation (Atkinson and Arey, 2003), it is not clear which mechanism is affected by RH. Non-volatile products like 2-methlyglyceric acid (2MGA) were not detected by PTR-ToF-MS.

However, there are notable exceptions to this observation: the production of glycolaldehyde (GLYC, $m / z 61.03$ ) and hydroxyacetone (HAC, $m / z$ 75.04) increased under humid conditions (Fig. 2c). At the end of the photooxidation period, the concentration of GLYC was $33 \mathrm{ppb}$ (dry) and $56 \mathrm{ppb}$ (humid) in the representative samples. Similarly, the concentration of HAC was $16 \mathrm{ppb}$ (dry) and $33 \mathrm{ppb}$ (humid). The signal at $\mathrm{m} / \mathrm{z}$ 61.03 and at $m / z, 75.04$ may have interferences from acetic acid and lactaldehyde, respectively. However, acetic acid is not expected to be a significant product on the timescale of the experiment (Lee et al., 2006; Paulot et al., 2009). Furthermore, lactaldehyde is not observed from the oxidation of isoprene in laboratory experiments or in field observations, so we do not expect these interferences to be significant. Conversely, GLYC and HAC are important watersoluble isoprene oxidation products commonly observed in the field (Lee et al., 1998; Spaulding et al., 2003; Matsunaga, 2005; Zhou et al., 2009; Williams et al., 2001; Matsunaga et al., 2003). GLYC is produced in the $\mathrm{OH}+\mathrm{MVK}$ reaction (Tuazon and Atkinson, 1989; Atkinson and Arey, 1998) and HAC is produced in the $\mathrm{OH}+\mathrm{MAC}$ reaction (Williams et al., 2001) following the photooxidation of isoprene. GLYC and HAC may also be formed from decomposition of alkenoxy radicals (Dibble, 2004b, a) or from the degradation of hydroxy alkenyl nitrates (Paulot et al., 2009). The increase in signal of these second-generation VOC at higher RH is unexpected, and cannot be explained by backward reactions in the PTR ion source.

The effect of RH on the resulting SOA mass in the chamber was insignificant. Figure $2 \mathrm{~d}$ shows the time-dependent SOA yield defined as the ratio of the dry SOA mass $\left(\mu \mathrm{g} \mathrm{m}^{-3}\right)$ produced over the concentration of isoprene reacted. This yield definition is not ideal as a large contribution to SOA mass arises from the oxidation of first generation products after all of the isoprene has already reacted (Kroll et al., 2005). However, for the sake of comparison, the traditional definition of SOA yield was used to gauge the relative differences between the two sets of data, without an emphasis on the absolute yield quantification.

Figure $2 \mathrm{~d}$ demonstrates that $\mathrm{RH}$ does not substantially affect the relative SOA yield from isoprene photooxidation in the absence of inorganic seeds. This result qualitatively agrees with conclusions of Dommen et al. (2006) who reported no significant change in the SOA yields at different $\mathrm{RH}$, also for SOA generated in the absence of inorganic seeds. However, our observations are different from the recent study of Zhang et al. (2011) who reported an enhancement of the SOA yield under dry conditions from isoprene photooxidation in $\left(\mathrm{NH}_{4}\right)_{2} \mathrm{SO}_{4}$-seeded experiments. The presence of inorganic seeds in the chamber is an important difference between these experiments. $\left(\mathrm{NH}_{4}\right)_{2} \mathrm{SO}_{4}$ particles exhibit significant hygroscopic growth at elevated $\mathrm{RH}\left(\mathrm{GF} \sim 1.5\right.$ at $85 \% \mathrm{RH}$ for $\left(\mathrm{NH}_{4}\right)_{2} \mathrm{SO}_{4}$ seeds; Virkkula et al., 1999; Cruz and Pandis, 2000), compared to organic particles (GF 1.0-1.1 for biogenic SOA (Virkkula et al., 1999; Varutbangkul et al., 2006)). The increased LWC in the seeded experiments likely has an effect on the SOA formation, and may account for the different conclusions of Zhang et al. (2011) vs. Dommen et al. (2006) and this work.

Under humidified conditions, the use of $\mathrm{H}_{2} \mathrm{O}_{2}$ as an $\mathrm{OH}$ precursor may lead to aqueous photochemistry occurring directly inside the wetted particles, potentially affecting the final SOA yield. This would be more of an issue for the seeded experiments, which have higher LWC. Dommen et al. (2006) performed "classical photooxidation" experiments without $\mathrm{OH}$ precursors. The good agreement between this work and that of Dommen et al. (2006) with respect to the 
$\mathrm{RH}$ effect on the SOA yields suggests that the specific choice of $\mathrm{OH}$ precursor and presence of $\mathrm{H}_{2} \mathrm{O}_{2}$ in the chamber is not important for the non-seeded experiments.

\subsection{Mass spectrometry analysis of SOA samples}

Figure 3 shows the stick mass spectra for isoprene photooxidation SOA generated under dry $(\mathrm{RH}<2 \%)$ and humid (RH $90 \%$ ) conditions. The horizontal axis corresponds to molecular weights of the neutral SOA compounds, which could be unambiguously assigned to $\mathrm{C}_{\mathrm{c}} \mathrm{H}_{\mathrm{h}} \mathrm{O}_{\mathrm{o}} \mathrm{N}_{\mathrm{n}}$ molecular formulas from the corresponding measured $m / z$ values. We are interested in the most complete set of compounds for our analysis regardless of their mode of detection. Mass spectra shown in Fig. 3 represent a merged set of ESI and nano-DESI data, which plots the average abundance of each molecule detected in different ionization modes. The background peaks from blank samples were removed. The negative and positive mode data with ion peak assignments in $\mathrm{m} / \mathrm{z}$ are converted to neutral masses and merged because negative and positive modes ionize different subsets of SOA compounds, and nano-DESI is more sensitive to compounds prone to solvolysis compared to ESI. Although the averaged mass spectral intensities do not represent the relative molecular abundances in the aerosol, they can still be used for qualitative comparison between the dry and humid samples. To ensure that the intensities in the mass spectra of dry and humid SOA samples can be compared, we recorded the mass spectra under identical instrumental settings. Approximately 750 peaks were assigned in each mass spectrum, representing $\sim 70 \%$ of all the observed peaks.

The monomer form of 2MGA was observed with high abundance in both dry and humid spectra, indicating that the formation pathway to produce 2MGA is not significantly affected by RH. For example, one formation pathway for 2MGA and its oligomers is the photooxidation of a secondgeneration product from isoprene methacryloylperoxynitrate (MPAN) (Surratt et al., 2010; Chan et al., 2010). Methyltetrols were not observed in the high- $\mathrm{NO}_{\mathrm{x}}$ data, consistent with the findings of Surratt et al. (2006). Figure 3 shows that the components of SOA generated under dry vs. humid conditions were quite different. Differences in peak intensities in the dry vs. humid samples did not result from an experimental artifact as in both cases the filters contained about the same amount of deposited SOA material. Furthermore, experiments with different filter loadings, $10 \mu \mathrm{g} \mathrm{m} \mathrm{m}^{-3}$ vs. $40 \mu \mathrm{g} \mathrm{m}^{-3}$ estimated by SMPS data, under a specific RH condition resulted in similar intensity distributions (Fig. S1).

Isoprene has a relatively low molecular weight $(68.063 \mathrm{Da})$ and even the heaviest products of isoprene oxidation that retain its original carbons have molecular weights under $200 \mathrm{Da}$ (for example, 2-methyltetrol nitrate ester weighs $181.058 \mathrm{Da}$ ). Figure 3 shows that $80-90 \%$ of the observed isoprene SOA constituents have molecular

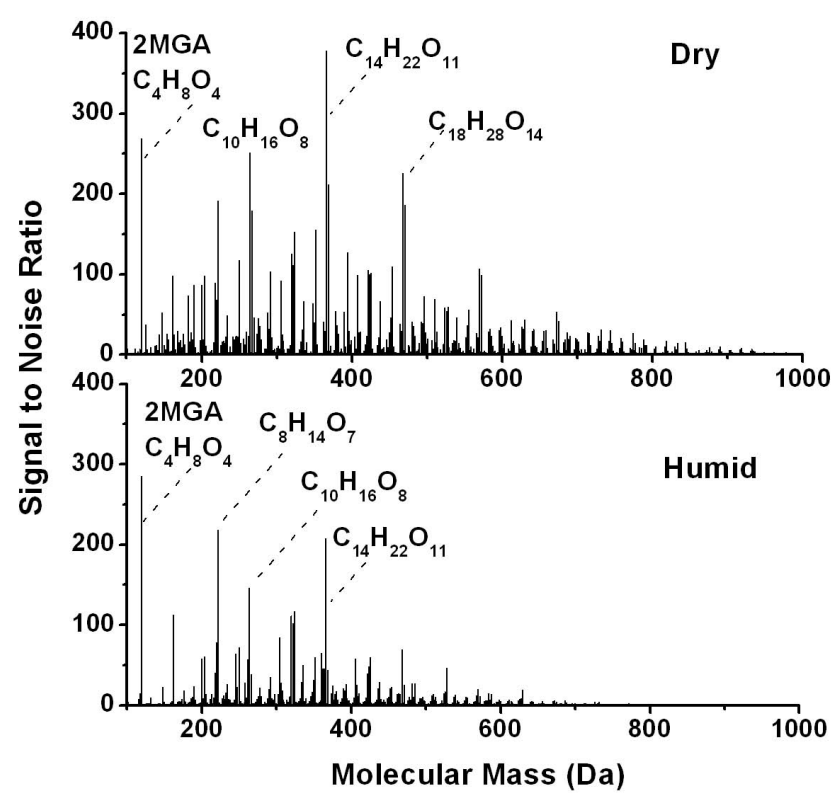

Fig. 3. Stick spectra of all assigned compounds in high- $\mathrm{NO}_{\mathrm{x}}$ isoprene SOA samples generated under two humidity conditions. The spectra represent a merged set of ESI and nano-DESI data. The horizontal axis corresponds to molecular weights of the neutral SOA compounds, and the vertical axis corresponds to the mass spectra intensities. High-MW oligomeric species in the dry sample are significantly more abundant.

weights in excess of $200 \mathrm{Da}$ and therefore correspond to oligomeric molecules. In the mass spectrum of the SOA generated under dry conditions, more peaks are observed in the 400-1000 Da region, whereas for the SOA formed under humid conditions most peaks are clustered around 200-400 Da. We note that oligomers may be overrepresented in our work as larger, multifunctional molecules are more efficient charge acceptors and are easier to ionize in the electrospray. Nevertheless, it is clear that oligomerization plays an important role in the SOA formation chemistry.

The highest abundance peaks, including those explicitly labeled in Fig. 3, are generally found in both dry and humid spectra. There are $\sim 550$ common peaks observed in both samples, corresponding to approximately $73 \%$ of the assigned peaks. However, there are significant and reproducible differences in the signal-to-noise $(\mathrm{S} / \mathrm{N})$ ratios of these peaks between the dry vs. humid spectra. The $\mathrm{S} / \mathrm{N}$ differences in the common peaks, under identical analytical conditions, suggest that RH affects the rate of production of these compounds. The amount of overlap between the two spectra decreased with an increase in $\mathrm{m} / \mathrm{z}$. For example, the overlap was $85 \%$ for molecular weights between 100-600 Da but only $36 \%$ for the $600-1000$ Da region. This trend logically implies that the formation of larger oligomers is hindered by high initial chamber RH (the discussion of the oligomers will be expanded upon in Sect. 4). 
Approximately $20 \%$ and $12 \%$ of the total number of peaks were assigned to NOC molecules in the dry and humid sample, respectively. In addition to the reduction in the total number of the observed NOC species, the $\mathrm{S} / \mathrm{N}$ of the NOC peaks in the humid mass spectra was greatly reduced. For example, $\mathrm{C}_{12} \mathrm{H}_{19} \mathrm{O}_{12} \mathrm{~N}$ (369.091 Da) was detected with a S/N of 212 in the dry sample vs. S/N of 44 in the humid sample. Similar drastic reduction in signal $(>80 \%)$ was observed for $\mathrm{C}_{8} \mathrm{H}_{13} \mathrm{O}_{9} \mathrm{~N}(267.059 \mathrm{Da}), \mathrm{C}_{16} \mathrm{H}_{25} \mathrm{O}_{15} \mathrm{~N}$ (471.122 Da), $\mathrm{C}_{20} \mathrm{H}_{31} \mathrm{O}_{18} \mathrm{~N}$ (573.154 Da), and several other NOC species. Most of these NOC are oligomers. The only monomeric nitrate observed is $\mathrm{C}_{4} \mathrm{H}_{7} \mathrm{O}_{3} \mathrm{NO}_{3}$ (the nitrate ester of 2MGA) and its signal is similarly low in both the dry and humid data ( $\mathrm{S} / \mathrm{N}$ of 1.6 and 1.5, respectively). The structural identities of selected NOC were probed with high-resolution tandem mass spectrometry ( $\left.\mathrm{MS}^{n}\right)$ and the detailed discussion is deferred to a subsequent manuscript (Nguyen et al., 2011). Briefly, most of the NOC molecules that are affected by $\mathrm{RH}$ are oligomeric organic nitrates with several 2MGA units incorporated into the structure. As an example, $\mathrm{MS}^{n}$ revealed $\mathrm{C}_{8} \mathrm{H}_{13} \mathrm{O}_{9} \mathrm{~N}$ to be a condensation dimer of $2 \mathrm{MGA}$ and its nitrate ester $\left(\mathrm{C}_{4} \mathrm{H}_{7} \mathrm{O}_{3} \mathrm{NO}_{3}+\mathrm{C}_{4} \mathrm{H}_{6} \mathrm{O}_{3}\right)$. In addition, to probing the structures, the $\mathrm{MS}^{n}$ studies confirmed unambiguously that the high-MW ions detected by the Orbitrap are strongly-bound covalent species, as opposed to weaklybound ionic complexes formed in the electrospray process (Nguyen et al., 2011).

Figure 4 compares peaks observed uniquely in samples generated under dry or humid conditions, with those of higher abundances explicitly labeled. There were approximately 220 unique peaks in the dry dataset and 225 unique peaks in the humid dataset, representing $\sim 37 \%$ of all the assigned 750 peaks by count. Because all of the unique peaks were of relatively low abundance $(\mathrm{S} / \mathrm{N}<40)$, their $\mathrm{MS}^{n}$ analysis could not be performed. However, a visual comparison shows that a large fraction of compounds formed uniquely under dry conditions belong to the higher-MW oligomers and NOC species. Some of these molecules could be attributed to high-MW condensation oligomers whose formation was hindered under the humid conditions. For example $\mathrm{C}_{28} \mathrm{H}_{44} \mathrm{O}_{21}$ (Fig. 4) is likely a 7-unit homologous $2 \mathrm{MGA}$ oligomer from the $\mathrm{C}_{4} \mathrm{H}_{8} \mathrm{O}_{3}+\left(\mathrm{C}_{4} \mathrm{H}_{6} \mathrm{O}_{3}\right)_{n}$ family (Table 1). Other molecules like $\mathrm{C}_{11} \mathrm{H}_{14} \mathrm{O}_{6}$ are formed from heterogeneous (comprised of different monomeric units) oligomerization because their molecular formulas are not linked to repeating units of any one monomer. These molecules are less likely to form in the humid conditions because high RH may hinder the formation of certain monomers. Although the number of observed unique peaks is similar for both the dry and humid data, the total ion signal for unique peaks in the dry data is much higher. This may suggest either higher physical abundance of those unique compounds in the sample or higher ionization efficiency in the electrospray.

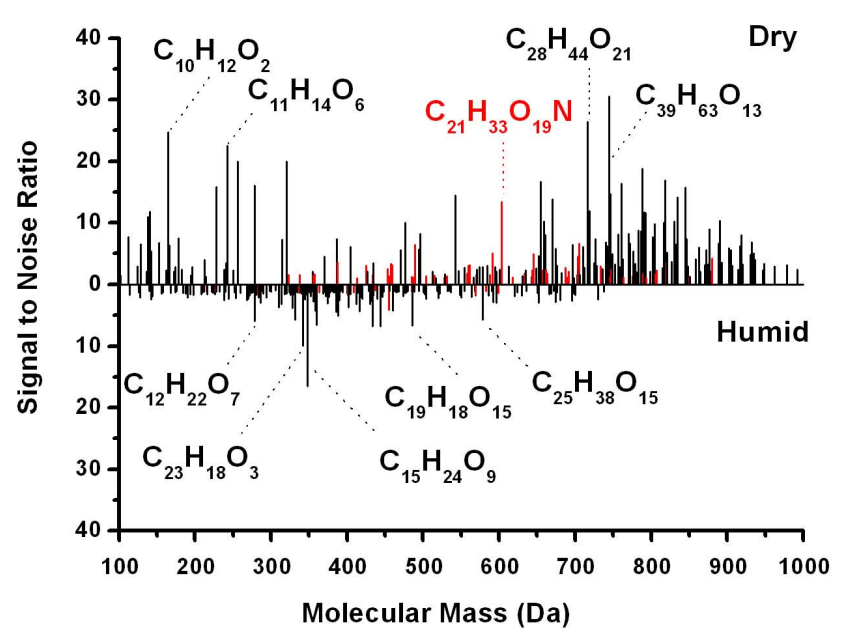

Fig. 4. Stick spectra of assigned compounds that are unique to either dry or humid conditions. The axes are defined in the same way as in Fig. 3. There are approximately 200 formulas unique to the dry conditions and 225 formulas unique to the humid conditions out of 750 assigned formulas in each sample. Unique formulas with higher abundances are labeled. NOC species are shown in red.

\section{Discussion}

The similarity in the time-dependent concentrations of reaction products and relative SOA mass yields in the dry and humid experiments suggests that the initial gas-phase oxidation chemistry was similar. The $\mathrm{OH}$ yield from the photolysis of $\mathrm{H}_{2} \mathrm{O}_{2}$ was likely minimally affected by the additional water vapor. However, the increase in signal of GLYC and HAC indicates that water vapor indeed affected a certain subset of photochemical reactions. As GLYC and HAC are both water-soluble, they should be lost more easily to the walls with higher initial water vapor in the chamber. Therefore, the increase in the abundances of these products in the gas phase under higher RH conditions is unexpected. Due to the multiple sources of GLYC and HAC, the reason behind this particular RH effect is unclear and a more systematic investigation is necessary to implicate specific reactions.

The observed reduction of the organic nitrates in the particle phase under humid conditions may be due to the following reasons. First, the total organic nitrates formed in the gas phase may be reduced, which would limit the number of particle-phase nitrates by gas-particle partitioning. Typically, VOC do not fragment in the PTR ion source; however, volatile organic nitrates $\left(\mathrm{RONO}_{2}\right)$ may lose nitrous acid $(-\mathrm{HONO})$, nitric acid $\left(-\mathrm{HNO}_{3}\right)$ or fragment into $\mathrm{NO}_{2}^{+}$ (Aoki et al., 2007; Perring et al., 2009a). As the identities of the individual nitrates are unknown, we cannot use carbon-based fragment ions formed in the PTR ion source, e.g. $[\mathrm{M}-\mathrm{HONO}]^{+}$or $\left[\mathrm{M}-\mathrm{HNO}_{3}\right]^{+}$, to trace the time evolution of the total amount of organic nitrates. We do observe a $40 \%$ decrease in the signal of $\mathrm{NO}_{2}^{+}$under humid conditions, 
Table 1. Total abundances of oligomers in the condensation and addition reactions from selected homologous families. Each condensation family is generated by a repeated addition of $\mathrm{C}_{4} \mathrm{H}_{6} \mathrm{O}_{3}$ to the $\mathrm{C}_{\mathrm{x}} \mathrm{H}_{\mathrm{y}} \mathrm{O}_{\mathrm{z}}$ precursor listed in the first column. The addition families are built by repeated addition of $\mathrm{C}_{2} \mathrm{H}_{4} \mathrm{O}_{2}$ to a $\mathrm{C}_{\mathrm{x}} \mathrm{H}_{\mathrm{y}} \mathrm{O}_{\mathrm{z}}$ precursor. $k_{\max }$ is defined as the maximum number of homologous oligomer units attached to the parent molecule, used as indicators of oligomer length, and $\Delta C$ is the change in the total number of carbon atoms in the oligomer, calculated based on the number of carbon in the monomer unit and the change in $k_{\max }$. Full data are reported in Tables S1 and S2 in the Supplement.

\begin{tabular}{lrrrrrr}
\hline Condensation & Dry & Dry & Humid & Humid & & \\
\hline $\mathrm{C}_{\mathrm{c}} \mathrm{H}_{\mathrm{h}} \mathrm{O}_{\mathrm{0}} \mathrm{N}_{n}+\left(\mathrm{C}_{4} \mathrm{H}_{6} \mathrm{O}_{3}\right)_{k}$ & Total Signal & $k_{\max }$ & Total Signal & $k_{\text {max }}$ & $\Delta$ Signal $(\%)$ & $\Delta \mathrm{C}$ \\
\hline $\mathrm{C}_{2} \mathrm{H}_{4} \mathrm{O}_{3}$ & 114 & 7 & 34 & 5 & -70 & -8 \\
$\mathrm{C}_{3} \mathrm{H}_{4} \mathrm{O}_{3}$ & 455 & 8 & 106 & 6 & -77 & -8 \\
$\mathrm{C}_{3} \mathrm{H}_{6} \mathrm{O}_{2}$ & 225 & 9 & 107 & 6 & -52 & -12 \\
$\mathrm{C}_{3} \mathrm{H}_{6} \mathrm{O}_{3}$ & 140 & 8 & 35 & 6 & -75 & -8 \\
$\mathrm{C}_{4} \mathrm{H}_{6} \mathrm{O}_{3}$ & 445 & 8 & 137 & 6 & -69 & -8 \\
$\mathrm{C}_{4} \mathrm{H}_{8} \mathrm{O}_{3}$ & 100 & 8 & 28 & 5 & -72 & -12 \\
$\mathrm{C}_{4} \mathrm{H}_{8} \mathrm{O}_{4}$ & 598 & 8 & 467 & 6 & -22 & -8 \\
$\mathrm{C}_{4} \mathrm{H}_{7} \mathrm{O}_{6} \mathrm{~N}$ & 736 & 7 & 126 & 6 & -83 & -4 \\
$\mathrm{C}_{5} \mathrm{H}_{8} \mathrm{O}_{4}$ & 291 & 8 & 124 & 5 & -57 & -12 \\
$\mathrm{C}_{5} \mathrm{H}_{8} \mathrm{O}_{5}$ & 491 & 7 & 167 & 5 & -66 & -8 \\
$\mathrm{C}_{6} \mathrm{H}_{8} \mathrm{O}_{4}$ & 165 & 7 & 88 & 4 & -47 & -12 \\
$\mathrm{C}_{6} \mathrm{H}_{10} \mathrm{O}_{5}$ & 1053 & 8 & 451 & 6 & -57 & -8 \\
$\mathrm{C}_{7} \mathrm{H}_{10} \mathrm{O}_{4}$ & 166 & 7 & 77 & 5 & -54 & -8 \\
\hline Average & 383 & 8 & 150 & 5 & $-63( \pm 16)$ & $-9( \pm 2)$ \\
\hline
\end{tabular}

\begin{tabular}{lrrrrrr}
\hline Addition & Dry & Dry & Humid & Humid & & \\
\hline $\mathrm{C}_{\mathrm{c}} \mathrm{H}_{\mathrm{h}} \mathrm{O}_{0} \mathrm{~N}_{n}+\left(\mathrm{C}_{2} \mathrm{H}_{4} \mathrm{O}_{2}\right)_{k}$ & Total Signal & $k_{\max }$ & Total Signal & $k_{\max }$ & $\Delta$ Signal $(\%)$ & $\Delta \mathrm{C}$ \\
\hline $\mathrm{C}_{3} \mathrm{H}_{4} \mathrm{O}_{2}$ & 32 & 3 & 21 & 3 & -34 & 0 \\
$\mathrm{C}_{5} \mathrm{H}_{6} \mathrm{O}_{2}$ & 131 & 4 & 69 & 4 & -48 & 0 \\
$\mathrm{C}_{5} \mathrm{H}_{6} \mathrm{O}_{4}$ & 212 & 4 & 101 & 4 & -52 & 0 \\
$\mathrm{C}_{6} \mathrm{H}_{8} \mathrm{O}_{3}$ & 49 & 3 & 40 & 3 & -19 & 0 \\
$\mathrm{C}_{6} \mathrm{H}_{8} \mathrm{O}_{4}$ & 502 & 3 & 324 & 3 & -35 & 0 \\
$\mathrm{C}_{7} \mathrm{H}_{8} \mathrm{O}_{4}$ & 161 & 6 & 81 & 5 & -50 & -2 \\
$\mathrm{C}_{7} \mathrm{H}_{8} \mathrm{O}_{5}$ & 282 & 5 & 108 & 5 & -62 & 0 \\
$\mathrm{C}_{7} \mathrm{H}_{10} \mathrm{O}_{5}$ & 83 & 3 & 39 & 3 & -53 & 0 \\
$\mathrm{C}_{8} \mathrm{H}_{10} \mathrm{O}_{3}$ & 74 & 5 & 61 & 5 & -18 & 0 \\
$\mathrm{C}_{8} \mathrm{H}_{10} \mathrm{O}_{5}$ & 599 & 6 & 388 & 5 & -35 & -2 \\
$\mathrm{C}_{8} \mathrm{H}_{10} \mathrm{O}_{6}$ & 165 & 4 & 122 & 4 & -26 & 0 \\
$\mathrm{C}_{9} \mathrm{H}_{12} \mathrm{O}_{4}$ & 51 & 5 & 143 & 5 & +177 & 0 \\
$\mathrm{C}_{9} \mathrm{H}_{12} \mathrm{O}_{5}$ & 194 & 4 & 148 & 5 & -24 & +2 \\
\hline Average & 195 & 4 & 127 & 4 & $-21( \pm 61)$ & $0( \pm 1)$ \\
\hline
\end{tabular}

which may in principle be used as a tracer ion for the total organic nitrates in PTR-ToF-MS. Unfortunately, due to strong interferences from nitric acid $\left(\mathrm{HNO}_{3}\right)$ (Perring et al., 2009b), the $\mathrm{NO}_{2}^{+}$signal cannot be exclusively assigned to organic nitrate fragmentation. In addition, the yield of $\mathrm{NO}_{2}^{+}$from larger alkyl nitrates is small (e.g. $3 \%$ yield for a branched $\mathrm{C}_{3}$ nitrate; Aoki et al., 2007). The yield of $\mathrm{NO}_{2}^{+}$from protonation of $\mathrm{HNO}_{3}$ is not known, however, we expect a significant build up of $\mathrm{HNO}_{3}$ during photooxidation, and even a small yield could make a large difference in the $\mathrm{NO}_{2}^{+}$signal. That reduction in gas-phase $\mathrm{HNO}_{3}$ under humid conditions is the dominant cause of the reduction in the $\mathrm{NO}_{2}^{+}$signal is consistent with the exceptional water solubility of $\mathrm{HNO}_{3}$. However, a humidity-induced reduction in gas-phase organic nitrates cannot be completely ruled out based on the PTRToF-MS observations.

The second possibility for the observed reduction of the organic nitrates in the particle phase is that the formation of condensation organic oligomers containing a $-\mathrm{ONO}_{2}$ group may decrease under humid conditions. This, in turn, may lead to a reduction in the ion current for the NOC compounds. The SOA may still contain monomer nitrates, but as 
monomers are likely to be less ionizable than oligomers, the observed total NOC signal should decrease with a decrease in the degree of oligomerization. The negligible $\mathrm{RH}$-induced change in observed signal of the monomer nitrate of $2 \mathrm{MGA}$ (Sect. 3.2), the only observed monomer NOC species, is consistent with a similar concentration of monomeric nitrates in the aerosol and decreased oligomerization.

Finally, the particle-phase nitrates may be reduced in the humid conditions by a suppression of direct esterification of alcohols by nitric acid $\left(\mathrm{HNO}_{3}\right)$, also a condensation-type process. Nitric acid concentration in these experiments may be sufficient for the efficient partitioning of $\mathrm{HNO}_{3}$ into the particle phase. If esterification of alcohols by $\mathrm{HNO}_{3}$ is the main reason for the suppression of NOC in humid experiments, the reduction in the yield of organic nitrates should be smaller under more realistic atmospheric conditions with much lower $\mathrm{NO}_{2}$ and $\mathrm{HNO}_{3}$ concentrations as compared to the chamber. Nevertheless, this process has implications for the total budget of NOC compounds in particles, especially in highly-polluted urban air environments.

The high resolution mass spectra shown in Fig. 3 suggest that 2MGA is formed in comparably high abundance in both dry and humid conditions. However, the oligomerization arising from $2 \mathrm{MGA}$ is significantly affected by RH. For systematic assessment of the oligomerization patterns in SOA formed under the dry and humid conditions, we conducted a statistical molecular weight (MW) difference analysis for all the assigned compounds. For $x$ different compounds, there are $x^{2}-x$ non-zero mass differences that can be grouped in a histogram to identify the most common MW differences. Each such difference can be assigned to a formula $\mathrm{C}_{\mathrm{c}} \mathrm{H}_{\mathrm{h}} \mathrm{O}_{\mathrm{o}} \mathrm{N}_{\mathrm{n}}$, where $\mathrm{c}, \mathrm{h}, \mathrm{o}$, and $\mathrm{n}$ can be positive or negative depending on the chemical process responsible for propagating this particular fragment through the distribution of formulas. It is possible to trace high-MW formulas to lowerMW ones by generating chemical "families" of the type $\mathrm{C}_{\mathrm{x}} \mathrm{H}_{\mathrm{y}} \mathrm{O}_{\mathrm{z}} \mathrm{N}_{\mathrm{w}}+\left[\mathrm{C}_{\mathrm{c}} \mathrm{H}_{\mathrm{h}} \mathrm{O}_{\mathrm{o}} \mathrm{N}_{\mathrm{n}}\right]_{k}$ where $\mathrm{C}_{\mathrm{x}} \mathrm{H}_{\mathrm{y}} \mathrm{O}_{\mathrm{z}} \mathrm{N}_{\mathrm{w}}$ is the smallest member of the family and $k$ is the number of times the difference formula is repeated. This type of analysis, which in essence identifies the most frequently repeated base formulas to use for a given distribution of compounds, is routinely performed in high resolution mass spectrometry (Reinhardt et al., 2007; Nguyen et al., 2010; Hughey et al., 2002; Altieri et al., 2008) to find monomer units that form long oligomer "families". Our criteria for identifying monomer units using this method are: (1) observation of a large number of families which have a broad range of $k$ values; (2) ability to link the formula difference to an expected product of isoprene oxidation. It is important to note that non-homologous oligomers, i.e. those including different monomer building blocks, may also be present in large numbers but they are harder to track down with statistical tools.

MW differences corresponding to $\mathrm{O}$-atom and $\mathrm{CH}_{2}$ are usually the most common differences for natural complex mixtures as these groups are present in the majority of organic molecules. Indeed for humid isoprene high- $\mathrm{NO}_{\mathrm{x}}$ data, the most common mass differences were $\mathrm{O}$-atom followed by $\mathrm{CH}_{2}$. However, the most common difference in dry isoprene high- $\mathrm{NO}_{\mathrm{x}}$ data was a more complex unit: $\mathrm{C}_{4} \mathrm{H}_{6} \mathrm{O}_{3}$ $(102.032 \mathrm{Da})$. This mass difference must correspond to the formation of oligomers via condensation reactions involving 2MGA (Surratt et al., 2006; Szmigielski et al., 2007), a very abundant molecule in both humid and dry SOA samples. However, the prevalence of this mass difference in only the dry sample supports that 2MGA-based oligomers are much more important when the SOA is generated under dry conditions. The polyfunctional nature of 2MGA (carboxylic acid and alcohol functionality) enables the formation of very long oligomers similar to the poly-condensation of glycolic acid to make polyesters in industrial applications (Fig. 5a). The molecular formula of $2 \mathrm{MGA}$ is $\mathrm{C}_{4} \mathrm{H}_{8} \mathrm{O}_{4}$ but with an $\mathrm{H}_{2} \mathrm{O}$ loss at every condensation step the repeated unit becomes $\mathrm{C}_{4} \mathrm{H}_{6} \mathrm{O}_{3}$.

The unit $\mathrm{C}_{2} \mathrm{H}_{4} \mathrm{O}_{2}$ was also identified as a prominent repeating motif in our analysis and assigned as the addition unit of GLYC (Fig. 2c). GLYC $\left(\mathrm{HO}-\mathrm{CH}_{2}-\mathrm{C}(\mathrm{O}) \mathrm{H}\right)$ is similar to 2MGA in that it is bifunctional (it is the simplest hydroxyaldehyde) and can produce relatively long homologous oligomers (Fig. 5b). Like any hydroxyaldehyde, GLYC can oligomerize by addition to form hemiacetals, and its hydrated form $\mathrm{HO}-\mathrm{CH}_{2}-\mathrm{C}(\mathrm{OH})_{2} \mathrm{H}$ can oligomerize by condensation. However, with the relatively low amount of water present in the particle (about $30 \%$ by volume under humid conditions) the contribution of the hydrated form should be small.

Therefore, the unit $\mathrm{C}_{4} \mathrm{H}_{6} \mathrm{O}_{3}$ was used in our analysis to represent homologous condensation with $2 \mathrm{MGA}$, and $\mathrm{C}_{2} \mathrm{H}_{4} \mathrm{O}_{2}$ was used to represent homologous addition with GLYC. We examined these two important types of oligomer families in detail to discern differences in oligomerization due to the additional water vapor present in the chamber at the time of aerosol formation. We note that while these two types of oligomers are among the most abundant, there are other types of condensation and addition oligomers in isoprene SOA that respond to RH in a qualitatively similar way.

Oligomers produced from 2MGA condensation chemistry are very large and generally homologous $\left(k_{\max }=4-9\right)$. The homologous nature of 2MGA oligomers, which dominate the signal abundance from the SOA samples generated at both high and low RH conditions may account for the semi-solid nature of biogenic SOA (Virtanen et al., 2010; Vaden et al., 2010). A number of long homologous families of the type $\mathrm{C}_{\mathrm{x}} \mathrm{H}_{\mathrm{y}} \mathrm{O}_{z}+\left(\mathrm{C}_{4} \mathrm{H}_{6} \mathrm{O}_{3}\right)_{k}$, with $k$ ranging from 1 up to 9 were identified (Table 1, also see Tables S1 and S2 in the Supplement). Table 1 reports the summed ion signal from all oligomers identified from a particular family under both dry and humid conditions. The total signals are reported as the sum of the signal-to-noise ratios within the entire chemical family. The change in signal is defined as the absolute difference between the humid and dry total signal relative, divided by the maximum of the two total signals. As expected, 
a)<smiles>[Y][C@H](C)OC(=O)C(C)(O)C(C)(C)C(=O)OC(C)C(=O)C(C)=O</smiles>

$\mathrm{C}_{3} \mathrm{H}_{4} \mathrm{O}_{3}$

$2 \mathrm{MGA}\left(\mathrm{C}_{4} \mathrm{H}_{8} \mathrm{O}_{4}\right)$

$\mathrm{C}_{3} \mathrm{H}_{4} \mathrm{O}_{3}+k\left(\mathrm{C}_{4} \mathrm{H}_{6} \mathrm{O}_{3}\right)$

b)

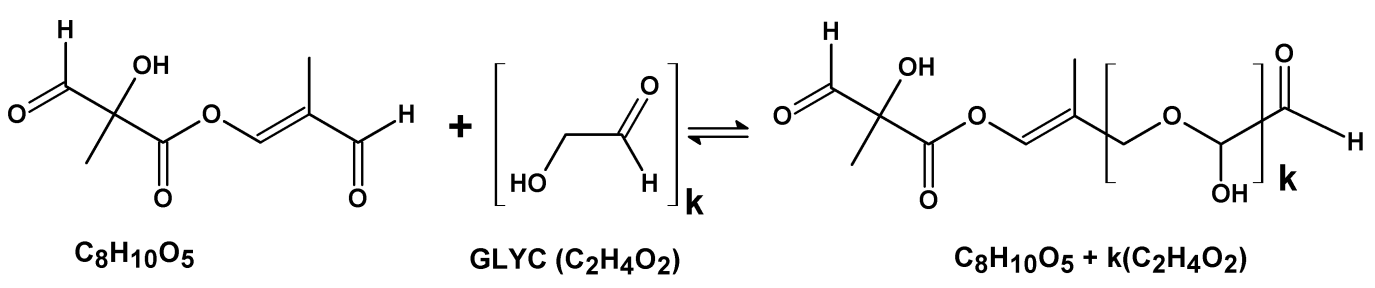

Fig. 5. (a) Condensation oligomerization from repeated esterification by $2 \mathrm{MGA}$ produces $\mathrm{MW}$ differences equivalent to $\mathrm{C}_{4} \mathrm{H}_{6} \mathrm{O}_{3}$. (b) Addition oligomerization from repeated hemiacetal formation with GLYC produces MW differences equivalent to $\mathrm{C}_{2} \mathrm{H}_{4} \mathrm{O}_{2}$.

$\mathrm{RH}$ affects the condensation oligomer chain length significantly. Homologous families of 2MGA are 2-3 monomer units shorter under humid conditions, corresponding to 7-11 fewer carbon atoms per molecule. The average decrease of condensation oligomers in SOA generated under humid conditions is $63 \pm 16 \%$, where the error in this case is the statistical spread in oligomer ion abundance between the thirteen homologous families included in Table 1.

Figure 6a shows the representative abundance distribution of the oligomers with molecular formulas $\mathrm{C}_{\mathrm{x}} \mathrm{H}_{\mathrm{y}} \mathrm{O}_{\mathrm{z}} \mathrm{N}_{\mathrm{w}}+$ $\left(\mathrm{C}_{4} \mathrm{H}_{6} \mathrm{O}_{3}\right)_{k}$. The trend of decreasing signal for each oligomer in the family, as well as a decrease in the length of the oligomers, at higher initial chamber RH is clearly observable. The distribution of oligomer signal shows that the most abundant oligomer in the family is not the same when SOA is generated under dry and humid conditions. For example, Fig. 6a reveals the most abundant oligomer in the family $\mathrm{C}_{3} \mathrm{H}_{4} \mathrm{O}_{3}+\left(\mathrm{C}_{4} \mathrm{H}_{6} \mathrm{O}_{3}\right)_{k}$ is the tetramer $(k=3)$ under dry conditions and the trimer under humid conditions. In general, the most abundant oligomer decreases by one monomer length in the chemical families studied in this work (Table S1). The signal distribution and oligomer length trends are similar for all the 2MGA-based families studied in this work (see Table S1 in the Supplement).

Figure $6 \mathrm{~b}$ shows a family of the type $\mathrm{C}_{\mathrm{x}} \mathrm{H}_{\mathrm{y}} \mathrm{O}_{\mathrm{z}}+\left(\mathrm{C}_{2} \mathrm{H}_{4} \mathrm{O}_{2}\right)_{k}$ formed by the repeated addition of GLYC $\left(\mathrm{C}_{2} \mathrm{H}_{4} \mathrm{O}_{2}\right)$. The signal distribution in Fig. $6 \mathrm{~b}$ is not significantly affected by $\mathrm{RH}$. The observed addition-type oligomers had $k_{\max }$ ranging from 3 to 6 . In contrast to the condensation-type oligomers, which uniformly decreased in abundance at high $\mathrm{RH}$, the addition-type oligomers did not display a clear trend $(-21 \pm 61 \%)$ in the total oligomer signal. However it is clear that, unlike the condensation oligomers, the oligomer chain length and number of carbon atoms are not affected by $\mathrm{RH}$ due to this type of addition reactions.

The evidence from high resolution mass spectrometry offers an important conclusion: the composition of isoprene

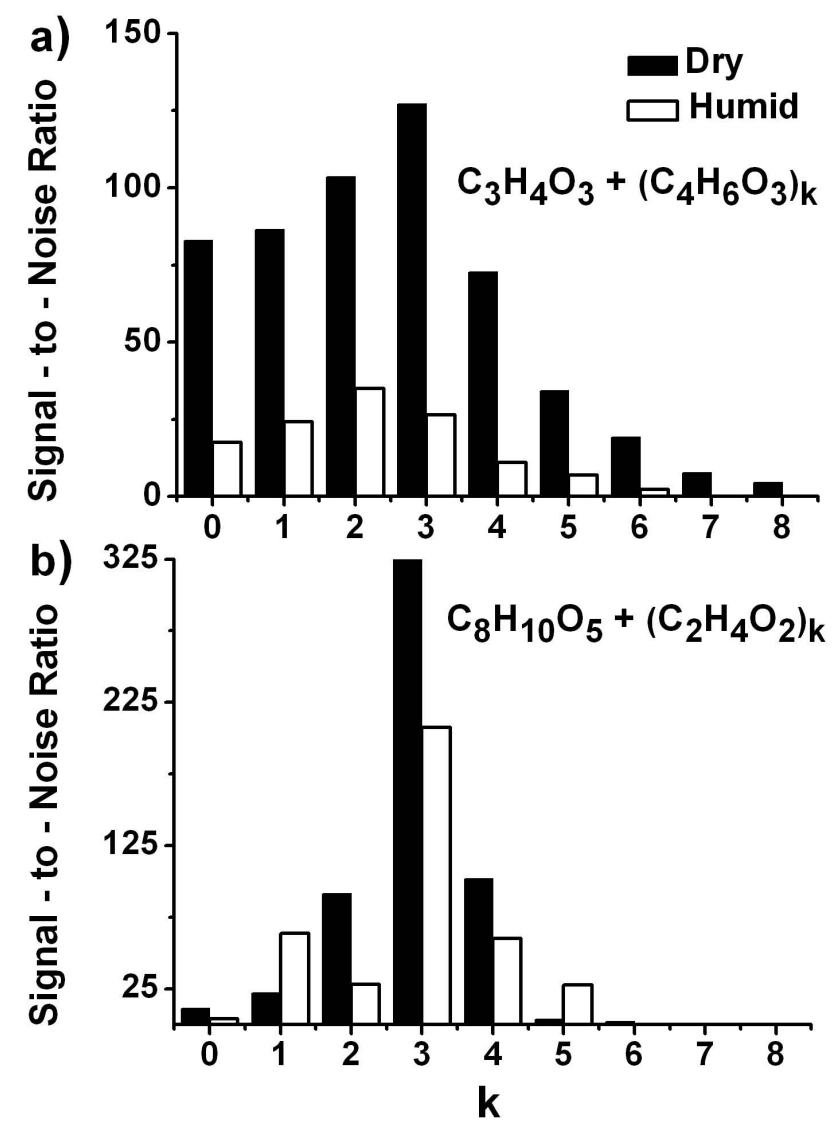

Fig. 6. Representative distributions of homologous oligomeric compounds in high- $\mathrm{NO}_{\mathrm{x}} \mathrm{SOA}$ under dry (filled bars) and humid (open bars) conditions. (a) Condensation-type oligomers from repeated esterification by $2 \mathrm{MGA}\left(\mathrm{C}_{4} \mathrm{H}_{8} \mathrm{O}_{4}\right.$ with one $\mathrm{H}_{2} \mathrm{O}$ lost per oligomerization step). (b) Addition-type oligomers incorporating homologous units of glycolaldehyde $\left(\mathrm{C}_{2} \mathrm{H}_{4} \mathrm{O}_{2}\right)$. 
photooxidation SOA changes considerably with $\mathrm{RH}$ even though the SOA mass yield appears to be unaffected. The rate of production of most of the volatile oxidation products in isoprene photooxidation remained the same regardless of $\mathrm{RH}$, with an important exception of GLYC and HAC (40$50 \%$ increase with high RH). The total number of aerosolphase NOC compounds also decreased by $40 \%$ in the humid mass spectra, and is most consistent with a reduction of oligomerization reactions involving monomeric NOC species. There are visible differences in the mass spectra with $\sim 37 \%$ unique products formed in either dry or humid conditions.

The common products observed under dry and humid conditions correspond mostly to condensation and addition oligomers and their relative abundances vary considerably between the two RH conditions. Our observations suggest that isoprene SOA formed under high RH conditions contain a significantly smaller number of high-MW homologous oligomers compared to the dry conditions due to a shift in chemical equilibria of the condensation reactions. The overall yield of all condensation oligomers decreased and the oligomers may be three monomer units shorter in SOA generated in humid air. In contrast, there is only a weak reduction in the number of addition-type oligomers obtained from our analysis but the data suggest the length of addition oligomers remain unchanged.

\section{Atmospheric implications}

The shorter chain length of oligomer esters produced under humid conditions $(\sim 5-7$ monomer residues, including parent) compared to those produced under dry conditions $(\sim 8$ 10 monomer residues) has important implications for the physical properties of the SOA. Consider for example, the solubility behavior of straight-chain oligomer esters of hydroxyacids, such as 2-methylglyceric acid (2MGA), where an inverse relationship between oligomer length and solubility is observed (Braud et al., 1996). Capillary electrophoresis experiments by Braud et al. (1996) determined that hydroxybutyric acid oligomers were no longer water-soluble at 5 monomer units long and glycolic acid oligomers were no longer water-soluble at 3 monomer units. Additionally, the viscosity of condensation oligomers increases with oligomer chain length (Yu et al., 2001).

As the water-solubility and viscosity of condensation oligomers are higher in SOA produced under dry conditions, the phase characteristics of the SOA may also change; for example, more viscous organic materials may be more "glassy" than less-viscous organic materials in their amorphous state. The less-viscous SOA can absorb water into the bulk, while the water uptake of the more-viscous SOA is limited by the surface (Mikhailov et al., 2009). Therefore, the water solubility and viscosity of the isoprene SOA, influenced by the total concentration of long-chain oligomers, may affect its hygroscopicity, or CCN ability. The hydroscopicity and morphology of particles were found to be important factors in the prediction and interpretation of $\mathrm{CCN}$ results (Hori et al., 2003). Isoprene SOA generated under dry conditions, where the composition is dominated by long oligomer esters, may exhibit reduced $\mathrm{CCN}$ activity compared to those generated under humid conditions. This prediction based on mass spectrometry data is in agreement with observations made by Poulain et al. (2010) that the hygroscopicity of $\alpha$-pinene ozonolysis SOA is directly proportional to the water mixing ratio present in the chamber during SOA formation. Although the hygroscopicity of isoprene photooxidation products generated with a variety of $\mathrm{VOC} / \mathrm{NO}_{\mathrm{x}}$ ratios have been investigated (King et al., 2010), no hygroscopic growth factor or $\mathrm{CCN}$ activity measurements have been reported for isoprene SOA generated under humid vs. dry conditions. As biogenic SOA represents a large fraction of the tropospheric aerosol budget, a systematic study of the hygroscopic properties of SOA from isoprene, for example, as a function of initial chamber RH is warranted.

\section{Supplementary material related to this article is available online at: http://www.atmos-chem-phys.net/11/6931/2011/ acp-11-6931-2011-supplement.pdf.}

Acknowledgements. The UCI group gratefully acknowledges support by the NSF grants ATM-0831518 and CHE-0909227. The PNNL group acknowledges support provided by the intramural research and development program of the W. R. Wiley Environmental Molecular Sciences Laboratory (EMSL), a national scientific user facility sponsored by the Office of Biological and Environmental Research and located at PNNL. PNNL is operated for the US Department of Energy by Battelle Memorial Institute under contract no. DE-AC06-76RL0 1830.

Edited by: F. Keutsch

\section{References}

Altieri, K. E., Seitzinger, S. P., Carlton, A. G., Turpin, B. J., Klein, G. C., and Marshall, A. G.: Oligomers formed through in-cloud methylglyoxal reactions: Chemical composition, properties, and mechanisms investigated by ultra-high resolution FT-ICR mass spectrometry, Atmos. Environ., 42, 1476-1490, 2008.

Alves, C., Gonçalves, C., Mirante, F., Nunes, T., Evtyugina, M., Sánchez de la Campa, A., Rocha, A., and Marques, M.: Organic speciation of atmospheric particles in Alvão natural park (Portugal), Environ. Monit. Assess., 168, 321-337, doi:10.1007/s10661-009-1116-1, 2010.

Aoki, N., Inomata, S., and Tanimoto, H.: Detection of c1-c5 alkyl nitrates by proton transfer reaction time-of-flight mass spectrometry, Int. J. Mass Spec., 263, 12-21, 2007.

Atkinson, R. and Arey, J.: Atmospheric chemistry of biogenic organic compounds, Acc. Chem. Res., 31, 574-583, doi:10.1021/ar970143z, 1998. 
Atkinson, R. and Arey, J.: Atmospheric degradation of volatile organic compounds, Chem. Rev., 103, 4605-4638, doi:10.1021/cr0206420, 2003.

Axson, J. L., Takahashi, K., De Haan, D. O., and Vaida, V.: Gasphase water-mediated equilibrium between methylglyoxal and its geminal diol, Proc. Nat. Acad. Sci. USA, 107, 6687-6692, doi:10.1073/pnas.0912121107, 2010.

Bahreini, R., Keywood, M. D., Ng, N. L., Varutbangkul, V., Gao, S., Flagan, R. C., Seinfeld, J. H., Worsnop, D. R., and Jimenez, J. L.: Measurements of secondary organic aerosol from oxidation of cycloalkenes, terpenes, and m-xylene using an aerodyne aerosol mass spectrometer, Environ. Sci. Technol., 39, 5674-5688, 2005.

Barsanti, K. C. and Pankow, J. F.: Thermodynamics of the formation of atmospheric organic particulate matter by accretion reactions - part 1: Aldehydes and ketones, Atmos. Environ., 38, 4371-4382, doi:10.1016/j.atmosenv.2004.03.035, 2004.

Barsanti, K. C. and Pankow, J. F.: Thermodynamics of the formation of atmospheric organic particulate matter by accretion reactions - 2. Dialdehydes, methylglyoxal, and diketones, Atmos. Environ., 39, 6597-6607, doi:10.1016/j.atmosenv.2005.07.056, 2005.

Braud, C., Devarieux, R., Garreau, H., and Vert, M.: Capillary electrophoresis to analyze water-soluble oligo(hydroxyacids) issued from degraded or biodegraded aliphatic polyesters, J. Polym. Environ., 4, 135-148, doi:10.1007/bf02067448, 1996.

Carlton, A. G., Wiedinmyer, C., and Kroll, J. H.: A review of Secondary Organic Aerosol (SOA) formation from isoprene, Atmos. Chem. Phys., 9, 4987-5005, doi:10.5194/acp-9-4987-2009, 2009.

Casale, M. T., Richman, A. R., Elrod, M. J., Garland, R. M., Beaver, M. R., and Tolbert, M. A.: Kinetics of acid-catalyzed aldol condensation reactions of aliphatic aldehydes, Atmos. Environ., 41, 6212-6224, 2007.

Chan, A. W. H., Chan, M. N., Surratt, J. D., Chhabra, P. S., Loza, C. L., Crounse, J. D., Yee, L. D., Flagan, R. C., Wennberg, P. O., and Seinfeld, J. H.: Role of aldehyde chemistry and $\mathrm{NO}_{\mathrm{x}}$ concentrations in secondary organic aerosol formation, Atmos. Chem. Phys., 10, 7169-7188, doi:10.5194/acp-10-7169-2010, 2010.

Claeys, M., Graham, B., Vas, G., Wang, W., Vermeylen, R., Pashynska, V., Cafmeyer, J., Guyon, P., Andreae, M. O., Artaxo, P., and Maenhaut, W.: Formation of secondary organic aerosols through photooxidation of isoprene, Science, 303, 1173-1176, 2004.

Corrigan, A. L., Hanley, S. W., and Haan, D. O.: Uptake of glyoxal by organic and inorganic aerosol, Environ. Sci. Technol., 42, 4428-4433, doi:10.1021/es7032394, 2008.

Couvidat, F. and Seigneur, C.: Modeling secondary organic aerosol formation from isoprene oxidation under dry and humid conditions, Atmos. Chem. Phys., 11, 893-909, doi:10.5194/acp-11893-2011, 2011.

Cruz, C. N. and Pandis, S. N.: Deliquescence and hygroscopic growth of mixed inorganic-organic atmospheric aerosol, Environ. Sci. Technol., 34, 4313-4319, 2000.

Dibble, T. S.: Intramolecular hydrogen bonding and double h-atom transfer in peroxy and alkoxy radicals from isoprene, J. Phys. Chem. A, 108, 2199-2207, doi:10.1021/jp0306702, 2004a.

de P. Vasconcelos, L. A., Macias, E. S., and White, W. H., Aerosol composition as a function of haze and humidity levels in the Southwestern US, Atmos. Environ., 28, 3679-3691, 1994.

Dibble, T. S.: Prompt chemistry of alkenoxy radical products of the double h-atom transfer of alkoxy radicals from isoprene, J. Phys. Chem. A, 108, 2208-2215, doi:10.1021/jp0312161, 2004b.

Dommen, J., Metzger, A., Duplissy, J., Kalberer, M., Alfarra, M. R., Gascho, A., Weingartner, E., Prevot, A.S.H., Verheggen, B., and Baltensperger, U.: Laboratory observation of oligomers in the aerosol from isoprene/NOx photooxidation, Geophys. Res. Lett., 33, L13805, doi:13810.11029/12006gl026523, 2006.

Ewing, G. E.: Thin film water, J. Phys. Chem. B, 108, 1595315961, 2004.

Finlayson-Pitts, B. J. and Pitts, J. N.: Chemistry of the upper and lower atmosphere: Theory, experiments, and applications, Academic Press, San Diego, 1040 pp., 2000.

Fu, T. M., Jacob, D. J., and Heald, C. L.: Aqueous-phase reactive uptake of dicarbonyls as a source of organic aerosol over eastern North America, Atmos. Environ., 43, 1814-1822, doi:10.1016/j.atmosenv.2008.12.029, 2009.

Ghorai, S., Laskin, A., and Tivanski, A. V. : Evidence of ketoenol tautomerism in deliquesced malonic acid particles, J. Phys. Chem. A, 115, 4373-4380, doi:10.1021/jp112360x, 2011.

Heald, C. L., Henze, D. K., Horowitz, L. W., Feddema, J., Lamarque, J. F., Guenther, A., Hess, P. G., Vitt, F., Seinfeld, J. H., Goldstein, A. H., and Fung, I.: Predicted change in global secondary organic aerosol concentrations in response to future climate, emissions, and land use change, J. Geophys. Res.-Atmos., 113, D05211, doi:05210.01029/02007jd009092, 2008.

Henze, D. K. and Seinfeld, J. H.: Global secondary organic aerosol from isoprene oxidation, Geophys. Res. Lett., 33, L09812, doi:09810.01029/02006GL025976, 2006.

Hewitt, C. N., Hayward, S., and Tani, A.: The application of proton transfer reaction-mass spectrometry (PTR-MS) to the monitoring and analysis of volatile organic compounds in the atmosphere, J. Environ. Monitor., 5, 1-7, 2003.

Hori, M., Ohta, S., Murao, N., and Yamagata, S.: Activation capability of water soluble organic substances as ccn, J. Aerosol Sci., 34, 419-448, 2003.

Hughey, C. A., Rodgers, R. P., and Marshall, A. G.: Resolution of 11,000 compositionally distinct components in a single electrospray ionization fourier transform ion cyclotron resonance mass spectrum of crude oil, Anal. Chem., 74, 4145-4149, 2002.

Iinuma, Y., Boge, O., Kahnt, A., and Herrmann, H.: Laboratory chamber studies on the formation of organosulfates from reactive uptake of monoterpene oxides, Phys. Chem. Chem. Phys., 11, 7985-7997, doi:10.1039/b904025k, 2009.

Inomata, S., Tanimoto, H., Kameyama, S., Tsunogai, U., Irie, H., Kanaya, Y., and Wang, Z.: Technical Note: Determination of formaldehyde mixing ratios in air with PTR-MS: laboratory experiments and field measurements, Atmos. Chem. Phys., 8, 273284, doi:10.5194/acp-8-273-2008, 2008.

Jang, M. and Kamens, R. M.: Atmospheric secondary aerosol formation by heterogeneous reactions of aldehydes in the presence of a sulfuric acid aerosol catalyst, Environ. Sci. Technol., 35, 4758-4766, 2001.

Jang, M., Carroll, B., Chandramouli, B., and Kamens, R. M.: Particle growth by acid-catalyzed heterogeneous reactions of organic carbonyls on preexisting aerosols, Envir. Sci. Technol., 37, 38283837, doi:10.1021/es021005u, 2003.

Jayne, J. T., Duan, S. X., Davidovits, P., Worsnop, D. R., Zahniser, M. S., and Kolb, C. E.: Uptake of gas-phase aldehydes by water surfaces, J. Phys. Chem., 96, 5452-5460, 
doi:10.1021/j100192a049, 1992.

King, S. M., Rosenoern, T., Shilling, J. E., Chen, Q., Wang, Z., Biskos, G., McKinney, K. A., Pöschl, U., and Martin, S. T.: Cloud droplet activation of mixed organic-sulfate particles produced by the photooxidation of isoprene, Atmos. Chem. Phys., 10, 3953-3964, doi:10.5194/acp-10-3953-2010, 2010.

Kroll, J. H., Ng., L. N., Murphy, S. M., Flagan, R. C., and Seinfeld, J. H.: Secondary organic aerosol formation from isoprene photooxidation under high- $\mathrm{NO}_{\mathrm{x}}$ conditions, Geophys. Res. Lett., 32, L18808, doi:18810.11029/12005GL023637, 2005.

Kroll, J. H., Ng, N. L., Murphy, S. M., Flagan, R. C., and Seinfeld, J. H.: Secondary organic aerosol formation from isoprene photooxidation, Environ. Sci. Technol., 40, 1869-1877, 2006.

Lee, A., Goldstein, A. H., Kroll, J. H., Ng, N. L., Varutbangkul, V., Flagan, R. C., and Seinfeld, J. H.: Gas-phase products and secondary aerosol yields from the photooxidation of 16 different terpenes, J. Geophys. Res., 111, D17305, doi:17310.11029/12006jd007050, 2006.

Lee, Y. N., Zhou, X., Kleinman, L. I., Nunnermacker, L. J., Springston, S. R., Daum, P. H., Newman, L., Keigley, W. G., Holdren, M. W., Spicer, C. W., Young, V., Fu, B., Parrish, D. D., Holloway, J., Williams, J., Roberts, J. M., Ryerson, T. B., and Fehsenfeld, F. C.: Atmospheric chemistry and distribution of formaldehyde and several multioxygenated carbonyl compounds during the 1995 Nashville/middle Tennessee ozone study, J. Geophys. Res., 103, 22449-22462, doi:22410.21029/22498jd01251, 1998.

Liggio, J., Li, S.-M., and McLaren, R.: Heterogeneous reactions of glyoxal on particulate matter: Identification of acetals and sulfate esters, Envir. Sci. Technol., 39, 1532-1541, doi:10.1021/es048375y, 2005a.

Liggio, J., Li, S. M., and McLaren, R.: Reactive uptake of glyoxal by particulate matter, J. Geophys. Res.-Atmos., 110, D10304, doi:10.1029/2004jd005113, 2005b.

Loeffler, K. W., Koehler, C. A., Paul, N. M., and De Haan, D. O.: Oligomer formation in evaporating aqueous glyoxal and methyl glyoxal solutions, Environ. Sci. Technol., 40, 6318-6323, doi:10.1021/es060810w, 2006.

Malloy, Q. G. J., Nakao, S., Qi, L., Austin, R., Stothers, C., Hagino, H., and Cocker, D. R.: Real-time aerosol density determination utilizing a modified scanning mobility particle sizer-aerosol particle mass analyzer system, Aerosol Sci. Technol., 43, 673-678, 2009.

Matsunaga, S., Mochida, M., and Kawamura, K.: Growth of organic aerosols by biogenic semi-volatile carbonyls in the forestal atmosphere, Atmos. Environ., 37, 2045-2050, 2003.

Matsunaga, S. N., Wiedinmyer, C., Guenther, A. B., Orlando, J. J., Karl, T., Toohey, D. W., Greenberg, J. P., and Kajii, Y.: Isoprene oxidation products are a significant atmospheric aerosol component, Atmos. Chem. Phys. Discuss., 5, 11143-11156, doi:10.5194/acpd-5-11143-2005, 2005.

Mikhailov, E., Vlasenko, S., Martin, S. T., Koop, T., and Pöschl, U.: Amorphous and crystalline aerosol particles interacting with water vapor: conceptual framework and experimental evidence for restructuring, phase transitions and kinetic limitations, Atmos. Chem. Phys., 9, 9491-9522, doi:10.5194/acp-9-9491-2009, 2009.

Moore, C. B. and Weisshaar, J. C.: Formaldehyde photochemistry, Ann. Rev. Phys. Chem., 34, 525-555, doi:10.1146/annurev.pc.34.100183.002521, 1983.

Nguyen, T. B., Bateman, A. P., Bones, D. L., Nizkorodov, S. A., Laskin, J., and Laskin, A.: High-resolution mass spectrometry analysis of secondary organic aerosol generated by ozonolysis of isoprene, Atmos. Environ., 44, 1032-1042, 2010.

Nguyen, T. B., Laskin, J., Laskin, A., and Nizkorodov, S. A.: Nitrogen Containing Organic Compounds and Oligomers in Secondary Organic Aerosol Formed by Photooxidation of Isoprene. Environ. Sci. Technol. , in press, doi:10.1021/es201611n, 2011.

Paulot, F., Crounse, J. D., Kjaergaard, H. G., Kroll, J. H., Seinfeld, J. H., and Wennberg, P. O.: Isoprene photooxidation: new insights into the production of acids and organic nitrates, Atmos. Chem. Phys., 9, 1479-1501, doi:10.5194/acp-9-1479-2009, 2009.

Perring, A. E., Bertram, T. H., Wooldridge, P. J., Fried, A., Heikes, B. G., Dibb, J., Crounse, J. D., Wennberg, P. O., Blake, N. J., Blake, D. R., Brune, W. H., Singh, H. B., and Cohen, R. C.: Airborne observations of total $\mathrm{RONO}_{2}$ : new constraints on the yield and lifetime of isoprene nitrates, Atmos. Chem. Phys., 9, 1451-1463, doi:10.5194/acp-9-1451-2009, 2009a.

Perring, A. E., Wisthaler, A., Graus, M., Wooldridge, P. J., Lockwood, A. L., Mielke, L. H., Shepson, P. B., Hansel, A., and Cohen, R. C.: A product study of the isoprene $+\mathrm{NO}_{3}$ reaction, Atmos. Chem. Phys., 9, 4945-4956, doi:10.5194/acp-9-4945-2009, 2009b.

Poulain, L., Wu, Z., Petters, M. D., Wex, H., Hallbauer, E., Wehner, B., Massling, A., Kreidenweis, S. M., and Stratmann, F.: Towards closing the gap between hygroscopic growth and $\mathrm{CCN}$ activation for secondary organic aerosols - Part 3: Influence of the chemical composition on the hygroscopic properties and volatile fractions of aerosols, Atmos. Chem. Phys., 10, 37753785, doi:10.5194/acp-10-3775-2010, 2010.

Reinhardt, A., Emmenegger, C., Gerrits, B., Panse, C., Dommen, J., Baltensperger, U., Zenobi, R., and Kalberer, M.: Ultrahigh mass resolution and accurate mass measurements as a tool to characterize oligomers in secondary organic aerosols, Anal. Chem., 79, 4074-4082, doi:10.1021/ac062425v, 2007.

Roach, P. J., Laskin, J., and Laskin, A.: Molecular characterization of organic aerosols using nanospray-desorption/electrospray ionization-mass spectrometry, Anal. Chem., 82, 7979-7986, doi:10.1021/ac101449p, 2010a

Roach, P. J., Laskin, J., and Laskin, A.: Nanospray desorption electrospray ionization: An ambient method for liquid-extraction surface sampling in mass spectrometry, Analyst, 135, 22332236, 2010b.

Shilling, J. E., Chen, Q., King, S. M., Rosenoern, T., Kroll, J. H., Worsnop, D. R., DeCarlo, P. F., Aiken, A. C., Sueper, D., Jimenez, J. L., and Martin, S. T.: Loading-dependent elemental composition of $\alpha$-pinene SOA particles, Atmos. Chem. Phys., 9, 771-782, doi:10.5194/acp-9-771-2009, 2009.

Spaulding, R. S., Schade, G. W., Goldstein, A. H., and Charles, M. J.: Characterization of secondary atmospheric photooxidation products: Evidence for biogenic and anthropogenic sources, J. Geophys. Res., 108, 4247, doi:4210.1029/2002jd002478, 2003.

Surratt, J., Chan, A. W. H., Eddingsaas, N. C., Chan, M., Loza, C. L., Kwan, A. J., Hersey, S. P., Flagan, R. C., Wennberg, P. O., and Seinfeld, J. H.: Reactive intermediates revealed in secondary organic aerosol formation from isoprene, Proc. Natl. Acad. Sci., 107, 6640-6645, 2010. 
Surratt, J. D., Murphy, S. M., Kroll, J. H., Ng, N. L., Hildebrandt, L., Sorooshian, A., Szmigielski, R., Vermeylen, R., Maenhaut, W., Claeys, M., Flagan, R. C., and Seinfeld, J. H.: Chemical composition of secondary organic aerosol formed from the photooxidation of isoprene, J. Phys. Chem. A, 110, 9665-9690, 2006.

Szmigielski, R., Surratt, J. D., Vermeylen, R., Szmigielska, K., Kroll, J. H., Ng, N. L., Murphy, S. M., Sorooshian, A., Seinfeld, J. H., and Claeys, M.: Characterization of 2-methylglyceric acid oligomers in secondary organic aerosol formed from the photooxidation of isoprene using trimethylsilylation and gas chromatography/ion trap mass spectrometry, J. Mass. Spectrom., 42, 101-116, 2007.

Tan, Y., Carlton, A. G., Seitzinger, S. P., and Turpin, B. J.: SOA from methylglyoxal in clouds and wet aerosols: Measurement and prediction of key products, Atmos. Environ., 44, 5218-5226, doi:10.1016/j.atmosenv.2010.08.045, 2010.

Tolocka, M. P., Jang, M., Ginter, J. M., Cox, F. J., Kamens, R. M., and Johnston, M. V.: Formation of oligomers in secondary organic aerosol, Envir. Sci. Technol., 38, 1428-1434, doi:10.1021/es035030r, 2004.

Tuazon, E. C. and Atkinson, R.: A product study of the gasphase reaction of methyl vinyl ketone with the oh radical in the presence of nox, Int. J. Chem. Kinet., 21, 1141-1152, doi:10.1002/kin.550211207, 1989.

Vaden, T. D., Imre, D., Beránek, J., Shrivastava, M., and Zelenyuk, A.: Evaporation kinetics and phase of laboratory and ambient secondary organic aerosol, Proc. Natl. Acad. Sci., 108, 21902195, doi:10.1073/pnas.1013391108, 2010.

van Donkelaar, A., Martin, R. V., Park, R. J., Heald, C. L., Fu, T.M., Liao, H., and Guenther, A.: Model evidence for a significant source of secondary organic aerosol from isoprene, Atmos. Environ., 41, 1267-1274, 2007.

Varutbangkul, V., Brechtel, F. J., Bahreini, R., Ng, N. L., Keywood, M. D., Kroll, J. H., Flagan, R. C., Seinfeld, J. H., Lee, A., and Goldstein, A. H.: Hygroscopicity of secondary organic aerosols formed by oxidation of cycloalkenes, monoterpenes, sesquiterpenes, and related compounds, Atmos. Chem. Phys., 6, 23672388, doi:10.5194/acp-6-2367-2006, 2006.

Virkkula, A., Van Dingenen, R., Raes, F., and Hjorth, J.: Hygroscopic properties of aerosol formed by oxidation of limonene, $\alpha$ pinene, and $\beta$-pinene, J. Geophys. Res., 104, 3569-3579, 1999.
Virtanen, A., Joutsensaari, J., Koop, T., Kannosto, J., Yli-Pirila, P., Leskinen, J., Makela, J. M., Holopainen, J. K., Pöschl, U., Kulmala, M., Worsnop, D. R., and Laaksonen, A.: An amorphous solid state of biogenic secondary organic aerosol particles, Nature, 467, 824-827, 2010.

Volkamer, R., Ziemann, P. J., and Molina, M. J.: Secondary Organic Aerosol Formation from Acetylene $\left(\mathrm{C}_{2} \mathrm{H}_{2}\right)$ : seed effect on SOA yields due to organic photochemistry in the aerosol aqueous phase, Atmos. Chem. Phys., 9, 1907-1928, doi:10.5194/acp9-1907-2009, 2009.

Wang, W., Kourtchev, I., Graham, B., Cafmeyer, J., Maenhaut, W., and Claeys, M.: Characterization of oxygenated derivatives of isoprene related to 2-methyltetrols in amazonian aerosols using trimethylsilylation and gas chromatography/ion trap mass spectrometry, Rapid Commun. Mass Spectrom., 19, 1343-1351, doi:10.1002/rcm.1940, 2005.

Williams, J., Pöschl, U., Crutzen, P. J., Hansel, A., Holzinger, R., Warneke, C., Lindinger, W., and Lelieveld, J.: An atmospheric chemistry interpretation of mass scans obtained from a proton transfer mass spectrometer flown over the tropical rainforest of surinam, J. Atmos. Chem., 38, 133-166, 2001.

Yu, Q., Nauman, S., Santerre, J. P., and Zhu, S.: Photopolymerization behavior of di(meth)acrylate oligomers, J. Mat. Sci., 36, 3599-3605, doi:10.1023/a:1017980523677, 2001.

Zelenyuk, A., Yang, J., Song, C., Zaveri, R. A., and Imre, D.: A new real-time method for determining particles' sphericity and density: Application to secondary organic aerosol formed by ozonolysis of alpha-pinene, Envir. Sci. Technol., 42, 8033-8038, doi:10.1021/es8013562, 2008.

Zhang, H., Surratt, J. D., Lin, Y. H., Bapat, J., and Kamens, R. M.: Effect of relative humidity on SOA formation from isoprene/NO photooxidation: enhancement of 2-methylglyceric acid and its corresponding oligoesters under dry conditions, Atmos. Chem. Phys., 11, 6411-6424, doi:10.5194/acp-11-6411-2011, 2011.

Zhou, X., Huang, G., Civerolo, K., and Schwab, J.: Measurement of atmospheric hydroxyacetone, glycolaldehyde, and formaldehyde, Environ. Sci. Technol., 43, 2753-2759, doi:10.1021/es803025g, 2009. 